\title{
The Drivers of Risk to Water Security in Shanghai
}

Brian L. Finlayson ${ }^{1 *}$, Jon Barnett ${ }^{1}$, Taoyuan $\mathrm{Wei}^{2}$, Michael Webber ${ }^{1}$, Maotian $\mathrm{Li}^{2}$, Mark Y. Wang ${ }^{1}$, Jing Chen ${ }^{2}$, Hao Xu ${ }^{3}$, Zhongyuan $\mathrm{Chen}^{2}$.

1. Department of Resource Management and Geography, University of Melbourne, Victoria 3010, Australia.

2. State Key Laboratory for Estuarine and Coastal Research, East China Normal University, 3663 Zhongshan Beilu, Shanghai, China, 200062.

3. Department of Geography, East China Normal University, 3663 Zhongshan Beilu, Shanghai, China, 200062.

* Corresponding author: $\mathrm{Ph}+6138344$ 9169; mobile +61408391573; email brianlf@unimelb.edu.au

Jon Barnett_ j jbarn@unimelb.edu.au

Taoyuan Wei_weit235@yahoo.cn

Michael J. Webber michaeljwebber@gmail.com

Maotian Li mtli@sklec.ecnu.edu.cn

Mark Y.Wang myw@unimelb.edu.au

Jing Chen_ jehen@geo.ecnu.edu.cn

Hao Xu_ dmhxu85@163.com

Zhongyuan Chen z.chen@sklec.ecnu.edu.cn 


\begin{abstract}
Big cities are often said to have big water problems, and Shanghai is no exception. In this paper we examine and compare the influence of the major factors that give rise to the risk of water insecurity in Shanghai. There is an extensive and diverse literature on these issues, dealt with in isolation, and here we provide a synthesis of the literature, together with our own assessments and calculations, to assess what are the risks to Shanghai's water supply and what is our degree of confidence in this assessment. We describe the systems that supply water to the city, and past and future changes in the systems, including changes in the glaciers that supply some water to the river, changes in climate, changes in land use, the construction of dams, and water diversions. We show how, at the same time as Shanghai is increasing its dependence on the Yangtze river, water diversions and sea-level rise are increasing the risk that this water will be too saline to consume at certain times of the year. This analysis suggests that most of the major drivers of the risk to water security in Shanghai are within the power of environmental managers to control.
\end{abstract}

Key words: climate change, sea-level rise, dams, South-North transfer, China, water scarcity. 


\section{The Drivers of Risk to Water Security in Shanghai}

\section{Introduction}

Water is now widely seen as one of the major problems for megacities such as Shanghai (National Research Council, 1996; McDonald et al., 2011). The UN Center for Human Settlements conference, Habitat II, held in 1996, predicted that by 2010 Shanghai would be one of the dozen cities in the developing world with the most severe water problems (N'Dow 1996). Since then, the Chinese government, international NGOs and senior academics have warned that droughts, climate change, declining runoff from catchments, pollution, inter-basin transfers and the construction of increasing numbers of large dams are putting at risk the supply of water to Shanghai, where population growth, rising living standards and industrial development are also raising the demand for water (see, for example: Wang 2010; Deng et al. 2011; Lu and Liang 2011; Wang 2011; World Wide Fund for Nature 2011).

Although Shanghai is understood to be a city to which the supply of water is not assured and where water quality is a serious issue (Hu, 2003; Ward and Liang, 1995; Zhao et al., 2006), the basic data on discharge and use, which we discuss below in Section 2, suggest that there is plenty of water for Shanghai's residents. One aim of this paper is to attempt to understand and resolve this contradiction - in what sense is a city in a humid climate zone and on such a large river short of water? Furthermore, present and projected developments within the Yangtze basin - climate change, land use changes, pollution, inter-basin transfers and the operation of large dams - appear to threaten to reduce the supply of water to Shanghai in the future. Shanghai is particularly vulnerable to these threats since it is the last municipality within the basin network to gain access to the river's water. Therefore, Shanghai is dependent for the security of its water supply on events in the upstream basin. This water insecurity is amplified, especially during extreme dry seasons, by the risk of increasing salinity due to future rises in sea level in the estuary from which Shanghai draws its water, (Shi et al., 2000; Chen and He, 2009). The second aim of this paper is therefore to 
understand the nature and magnitude of these multiple drivers of risk to Shanghai's water security.

In this paper we use existing data and commentary, as well as estimates and calculations of our own, to assess what are the risks to Shanghai's water supply and what is our degree of confidence in these assessments. The paper's contribution is to synthesise these independent lines of evidence to provide a comprehensive, integrated assessment of the drivers of risk to Shanghai's water supply security.

We begin with a brief examination of demand for water in Shanghai and a description of the water supply system. This is followed by a discussion of the trends in water availability in the Yangtze catchment, where we deal successively with the degradation of glaciers in the upper catchment, changes in temperature and precipitation, land use changes, urbanization, water quality, the construction of dams and inter-basin water transfers out of the Yangtze system. We do not consider pollution, except in so far as it has affected the Shanghai government's decisions about water supply; nor do we examine the administration and ownership of Shanghai's water system: both of these are large topics in their own right. Finally we summarise these drivers of risk and indicate the level of confidence we have in these assessments.

\section{Water Demand in Shanghai}

Shanghai is by any measure a massive city, whose population and economy is growing fast. The municipality is home to 23 million people, a population that increased by over 5 million between 2005 and 2010 (State Statistical Bureau 2011). Its economy has grown faster than the national average: in the period 1994-2000 Shanghai's average annual GDP growth rate was 14.7 per cent, and during 2000-2007 it was 9.8 per cent (Golley 2010). Shanghai's total water use has also been increasing. From 2006 to 2010 the total increase was $6.5 \%$, or 1.6\% per year (Shanghai Water Authority, 2007).

Of all the water used in Shanghai, about $59 \%$ is used to cool power stations, $\sim 14 \%$ is used for agriculture, $\sim 10 \%$ is used by households, $\sim 9 \%$ is used for public open spaces, and $\sim 8 \%$ is used by industry (other than power stations). Most of the water for residential and urban public space is processed through water treatment plants, as is 
about half of the 'other industrial' water (Figure 1). In the other cases, water is sourced directly by users, mainly from the Yangtze and the Huangpu rivers. The largest users of water in Shanghai are the power stations, though it should be noted that their actual consumption is less than that shown above, and in Figure 1, as $>80 \%$ of their water is returned to source after use for cooling and ash washing. Power station water use is also not particularly sensitive to water quality (Zhang, 1999; Han 2010).

\section{Insert Figure 1 here}

As explained in the following section, most of Shanghai's freshwater is supplied by the Yangtze River, which is the world's third largest river (by discharge). Mean annual discharge of the Yangtze over the period 1951 to 2008 as measured at the lowest gauging station (at Datong) is $90010^{9} \mathrm{~m}^{3}$ (Yang et al., 2011), so water availability in the whole basin is $2043 \mathrm{~m}^{3} /$ person $\mathrm{yr}^{-1}$. This is about half the average for Asia as a whole but compares with other developed, humid zone countries such as central and southern Europe (3330 $\mathrm{m}^{3} /$ person $\mathrm{yr}^{-1}$ ) and Germany and Poland (1665 $\mathrm{m}^{3} /$ person $\mathrm{yr}^{-1}$ ) (Falkenmark 1986). The ratio of water withdrawals to water availability in the Yangtze basin is far lower than in the Yellow, Chao Praya, Ganges and Indus basins and not significantly different from that in Asia's other large monsoonal basins (Varis et al. 2011). Indeed, the World Resources Institute (2003) has classified the Yangtze River basin as one of low water stress in terms of volume available.

In summary, assessment of the overall annual water demand in Shanghai can reasonably disregard the water used in the power stations since over $80 \%$ is returned to source and in any case salt water from the estuary can be used for this purpose. Shanghai's total annual (non-power station) fresh water demand is therefore 5.2 $10^{9}$ $\mathrm{m}^{3}$ which is only $0.6 \%$ of the mean annual flow at Datong. Assessed in this way it can be argued that total water demand is not a driver of water insecurity in Shanghai and is unlikely to become so in the foreseeable future. In what follows in this paper we refine this assessment in the light of other variables.

\section{Sources of Supply to Shanghai}

Until recently Shanghai sourced over $80 \%$ of its water from Taihu via the Huangpu River where the first treatment plant (in central Shanghai at Yangshupu) was built by 
foreign concession holders in 1881 (Shanghai Municipal Government, 2009; Figure 2). The remainder comes directly from the Yangtze, local surface water sources within the Shanghai area and groundwater. Water continues to be extracted from the Huangpu River, but the water intake has been shifted upstream near Taihu, due to heavy pollution in the river downstream (Zhang, 1997). Taihu, which is outside the Shanghai municipal boundary, has its own topographic catchment. Taihu, and consequently the Huangpu River, is now seriously polluted, an issue largely beyond the control of the Shanghai municipality, and the present pollution level is unlikely to be reduced in the foreseeable future (Chen et al, 2002).

\section{Insert Figure 2 here}

While significant volumes of groundwater were used in the past in Shanghai, its use is now being phased out because it caused serious ground subsidence. Average subsidence rates of $40 \mathrm{~mm} \mathrm{yr}^{-1}$ occurred in central Shanghai between 1920 and the mid-1960s due to heavy extraction of underground water (ca. $0.210^{9} \mathrm{~m}^{3} \mathrm{yr}^{-1}$ ). However, much reduced pumping and groundwater recharge (ca. 0.002- $0.01010^{9} \mathrm{~m}^{3}$ $\mathrm{yr}^{-1}$ ) has reduced the subsidence rate to ca. $2 \mathrm{~mm} \mathrm{yr}^{-1}$ since the mid-1960s (Wei et al., 2010).

Given these problems, the Shanghai Municipal Government developed a long-term strategy to draw water directly from the lower Yangtze estuary. The pumping station and storage facility at Chenghang (Figure 2) was opened in 1996. Since the Chenghang Reservoir has capacity to store only about 8 days supply, a larger intake and storage pond on the Yangtze estuary at Qingcaosha on Changxing Island was completed in 2011. When Qingcaosha is fully operational it will store 68 days of water supply, at which time $70 \%$ of the water supply to Shanghai's treatment plants can be sourced from the Yangtze (Shanghai Municipal Government 2010).

As of 2009 there were 118 water treatment plants in Shanghai and the majority of the water for residential and public uses is processed through these plants prior to distribution (Shanghai Municipal Government, 2009). This treated water is not considered safe to drink without first being boiled. There is, therefore, a significant market in bottled water in Shanghai.

There is currently no interest in the kinds of local water recycling schemes that are becoming increasingly popular in cities elsewhere, and the proportion of water being 
sourced locally (within the municipality) is declining in favour of water sourced from the Yangtze, as described above. This is despite the fact that Shanghai is located in a humid climate zone with mean annual precipitation of $1200 \mathrm{~mm}$ and with $697 \mathrm{~km}^{2}$ of surface water ( $11 \%$ of total area, in the form of lakes and rivers) within its boundaries (Shanghai Municipal Government, 2009). This increasing reliance on the Yangtze is driven by the fact that the water sources available within the city are of poor quality and include some pollutants that are difficult to remove in treatment plants (Chen et al., 2002; Le et al., 2005; Li et al., 2008). These pollutants are the result of fertiliserrich agricultural runoff, household waste, sewage and ineffectively treated industrial effluents (Chen et al., 2002).

So, Shanghai depends for water supply on the catchment areas of Taihu and the Yangtze River. We now briefly describe these catchments and their hydrological characteristics.

Taihu receives inflows from a catchment area of relatively low relief, up to 300-500 $m$ in elevation (Figure 2). The Tiaoxi River is the largest source of inflow and the rest comes from the western highlands and precipitation directly on to the lake water surface. Estimates of the runoff into Taihu from its catchment vary. Using runoff in the rivers entering the lake in 1984 (a normal year) plus rainfall directly on to the lake surface we estimate annual runoff into the lake as $8.2710^{9} \mathrm{~m}^{3}$; Jiang et al. (2008) estimated runoff into the lake in 2002 as $6.5710^{9} \mathrm{~m}^{3}$; while Zhu (1994) gives a figure of $7.610^{9} \mathrm{~m}^{3}$. Given that parts of Jiangsu and Zhejiang Provinces also draw their water from Taihu, the system is over-committed and must be supplemented from the Yangtze.

The catchment of the Yangtze River (Figure 2), the largest river basin in China, is 1.8 $10^{6} \mathrm{~km}^{2}$. Mean annual precipitation ranges from $1200 \mathrm{~mm}$ in the east and central sections of the catchment to less than $500 \mathrm{~mm}$ in the western section on the elevated Tibetan Plateau (Chen et al., 2010). The wettest part of the catchment is the downstream low-elevation section, while the driest parts of the catchment are in the western mountainous regions. Total discharge of the Yangtze is measured at Datong gauging station, located some $600 \mathrm{~km}$ upstream from the river mouth, where there is no tidal influence (salt water penetrates to approximately $340 \mathrm{~km}$ from the mouth). Mean annual discharge at Datong is $90010^{9} \mathrm{~m}^{3}(1951-2008)$ with a distinct summer maximum as shown in Figure 3. 
Insert Figure 3 here

Flow in the Yangtze is seasonal, with more than $70 \%$ of the annual flow occurring in the summer season (May to October). It has extremely low interannual variability by world standards. The coefficient of variation of annual flows is 0.15 , compared with the global average for rivers in the same climate zone of 0.34 (McMahon et al., 1992). At present, therefore, the Yangtze at Datong provides water that is reliable from yearto-year, but with strong seasonal fluctuations. Even in the month of lowest mean flow (January, $11.710^{9} \mathrm{~m}^{3}$ ); the Yangtze flow is more than six times the average monthly water use of Shanghai $\left(\sim 1.7 \times 10^{9} \mathrm{~m}^{3}\right)$. Therefore the problem of low flow is not that supply fails to meet demand at key times: as we shall see, the problem is the effect of low flow on salinity in the estuary from which Shanghai is increasingly drawing its water. The following section explains how changes in the Yangtze basin seem likely to increase the frequency of these difficult periods of low flow.

\section{Trends in water yields from the Yangtze}

Discharge has been measured continuously at Datong since 1951, and over this period there has been only a slight decrease in mean annual flow [-0.017 $10^{9} \mathrm{~m}^{3} \mathrm{yr}^{-1}$ ] (Yang et al., 2005). This is despite changes in the catchment that might have been expected to affect water yield in the past, although as we explain, these past changes may not be a good guide to the future. Here we review the major kinds of past and future changes in the catchment and what is known about their likely effects on yields, namely: the degradation of glaciers in the Yangtze River Source Region (YRSR), temperature and precipitation changes, changes in land use, the construction of dams, and the development of water transfer projects.

\subsection{Glacier degradation}

The glaciers in the upper catchment of the Yangtze have been retreating for some time, a trend that is expected to accelerate under future climate change scenarios (Liu et al., 2009). There are 1332 glaciers in the upper basin of the Yangtze with a total area of $1894.98 \mathrm{~km}^{2}$ and total ice volume of $147.52 \mathrm{~km}^{3}$. Within the Yangtze River 
Source Region (YRSR, Figure 2) there are 753 glaciers with total area of $1276.02 \mathrm{~km}^{2}$ and ice volume of $104.409 \mathrm{~km}^{3}$, accounting for $56.5 \%, 67.3 \%$ and $70.9 \%$ of the total number, area and volume, respectively, of all glaciers in the Yangtze River basin (Shi et al., 2005). However, changes to these glaciers during the past 50 years have been documented only for a limited number of glaciers in the Geladandong section of the YRSR (Figure 2).

Of all the 'Asian water towers', those in the YRSR are particularly sensitive to global warming (Immerzeel et al. 2010). Annual average temperature has increased $0.61^{\circ} \mathrm{C}$ in the YRSR within the past 50 years and this increase has accelerated during and since the 1990s (Xie et al., 2004). Correspondingly, the glacier area has decreased by about $1.7 \%$ from 1969 to 2000 in the Geladandong section of the YRSR. During the period 1969-2000, more glaciers retreated than extended and the maximum rate of retreat of glacier termini reached $41.5 \mathrm{~m} \mathrm{yr}^{-1}$ (Yang et al., 2003).

These trends have been cause for alarm in popular commentaries (see for example, China View, 2009) and scientific papers (see for example Chen X et al., 2001). This ignores evidence about the significance of glaciers to flows from the YRSR, and of flows from the YRSR to the whole catchment. Glacier meltwater is only $11 \%$ of the total river runoff of the YRSR. Furthermore, annual average runoff at Zhimenda station (controlling station of the YRSR, Figure 2) is only $0.13 \%$ of the runoff of the whole Yangtze basin (Xie et al., 2004; Liu et al., 2009). So, although glacier meltwater has increased during the past 50 years, and is predicted to increase in the future with climate warming, it still contributes only a tiny proportion of the total runoff of the whole Yangtze catchment. Total glacier ice volume in the Yangtze catchment is $147.5210^{9} \mathrm{~m}^{3}$ (Shi et al., 2005) and if we assume a water equivalent of 0.9 this is $132.510^{9} \mathrm{~m}^{3}$ of liquid water, equivalent to only $15 \%$ of the mean annual flow of the Yangtze at Datong. So, even if all the glaciers in the Yangtze catchment were to melt, the increased runoff would have little impact on runoff from the whole catchment - either the annual total or its seasonality. Likewise, if there were no glaciers left to melt, this region would continue to supply flow into the Yangtze system at a rate determined by the catchment water balance. Future melting of glaciers is not therefore a major problem for water supply to Shanghai.

\subsection{Temperature and precipitation changes}


For the whole Yangtze basin, annual runoff in the period since 1951 has shown no significant change, despite the fact that there has been a massive increase in population and substantial economic development. Runoff is strongly correlated with precipitation, indicating that other drivers had little influence over this period $(\mathrm{Xu} \mathrm{K}$ et al., 2010). According to Jiang et al. (2005) and Xu K et al. (2010), annual temperature has increased significantly since 1990 in the Yangtze catchment, while annual precipitation has not changed much during the past 50 years.

There has, however, been a significant change in the seasonal distribution of precipitation and discharge during the past 50 years. Monthly areal precipitation over the whole basin reveals statistically significant upward trends in January, March, June, and July and downward trends in April, May, September, and December, which is reflected in trends in runoff. Generally speaking, runoff has increased in winter and summer and decreased in spring and autumn (Jiang et al., 2005, 2008; Qin et al., 2005). These changes in precipitation have been ascribed to changes in the monsoon pattern, driven by changes in the large-scale atmospheric circulation associated with increasing sea surface temperature in the East China Sea (Zhang et al., 2008; Tang et al., 2009).

It has been predicted that temperature in the Yangtze catchment will continue to increase in all seasons during the next 50 years, and that precipitation will increase in winter and summer and decrease in autumn (Bueh et al., 2003; Zeng et al., 2007). The modeling by Bueh et al. (2003), based on future climate predictions of the IPCC for the mid $21^{\text {st }}$ century, indicate that temperature will be increased in all months of the year by between 1.5 and $3^{\circ} \mathrm{C}$ and that the increase will be least in mid-summer, thus minimizing its impact on evapotranspiration rates. In the early and mid-summer, the Yangtze River discharge is predicted to increase, mainly due to the large increase in precipitation in the preceding months, which has been stored in the catchment as snow or groundwater. The modeling also shows that the discharge of the Yangtze is predicted to decrease in the late summer and autumn, to which both increased evaporation and an early retreat of the monsoon rainfall contribute. While the predicted decline in runoff occurs in late summer and autumn, and could be as high as $5,000 \mathrm{~m}^{3} \mathrm{~s}^{-1}$, it should be noted that this is not the period of lowest flows and average monthly discharges range from $42,873 \mathrm{~m}^{3} \mathrm{~s}^{-1}$ in August to $32,785 \mathrm{~m}^{3} \mathrm{~s}^{-1}$ in September (Figure 3). The extent to which changes like these will affect fresh water availability 
in the lower estuary where Shanghai draws its water depends more on the size of extractions, particularly for the S-N transfers, and effect of sea level changes on salt water intrusion than on the actual climate driven changes alone.

\subsection{Land use changes}

Natural changes and increasing, and often inappropriate, human activities have caused dramatic land use changes in the Yangtze catchment over the last few decades. Here we consider the impacts of these on runoff in the Yangtze catchment. We identify in turn the effects of changes in vegetation cover, soil erosion, and urbanization.

The comprehensive review of the hydrological impact of changes in vegetation cover by Andreassian (2004) identifies consistent relationships between forests and hydrology. These are that annual streamflow increases following deforestation and decreases following re-afforestation; that deforestation can increase flood peak and total flood volume but this is more variable than the impact on annual flow and can in some cases be inverted; that re-afforestation has little effect on floods in general and no effect on large floods; and that deforestation increases low flows and reafforestation decreases them.

From 1950 to 1989 the area of forest cover in the Yangtze River catchment decreased dramatically, mainly because of land reclamation, farming on steep slopes and urbanization. In the 1950s, the proportion of the Yangtze catchment under forest was $\sim 22 \%$, and this fell to $10 \%$ by the 1980s (Li et al., 2000; Feng et al., 2010). Some reafforestation has occurred since 1989, so that the current forest cover of the Yangtze basin exceeds $29.5 \%$ (more than in 1950) with most of the forested area in the mountainous regions of the upper Yangtze where soil erosion is severe (CWCC, 2007). These basin-wide afforestation projects, especially those implemented after 1998 , have been reported in some regions to favour species that are of economic value and grow rapidly, in order to maximize economic returns. As a result, according to Feng et al. (2010), the water regulating function of afforestation has been diminished. As Wei et al. (2008) point out, the influence of forests on runoff is not stationary but varies through the life cycle of the stand. Since more than half the runoff, as measured at Datong, originates from the middle to lower Yangtze, driven by the summer monsoon (Chen $\mathrm{Z}$ et al., 2001), the effects of decreased runoff in response to 
increased forest cover in the upper catchment may be difficult to detect at Datong station.

The upper Yangtze basin has the worst soil erosion in the catchment, due to severe deforestation, farming on steep slopes and frequent slope failures (Li et al., 2000). In 1957 , the region affected by soil erosion was $36.3810^{4} \mathrm{~km}^{2}$ (some $20.2 \%$ of the catchment), which increased to $73.9410^{4} \mathrm{~km}^{2}$ (41.0\% of the catchment) by 1986 ( $\mathrm{Li}$, 1999; Li et al., 2000). Due to the massive afforestation in the Yangtze basin, the area of soil erosion decreased to $\sim 53.110^{4} \mathrm{~km}^{2}$ by the end of the 1990s (CWCC, 2007). The destruction of surface soil directly reduces infiltration and water storage capacity, and so this loss of soil by erosion in the Yangtze may significantly affect the generation of river flow.

Based on the calculations of Shi et al. (1999), the entire upper Yangtze, with an area of ca. $10010^{4} \mathrm{~km}^{2}$ and average soil thickness of $0.78 \mathrm{~m}$, can provide water storage of about $19710^{9} \mathrm{~m}^{3}$ - equivalent to $45 \%$ of the annual runoff of the upper Yangtze $\left(438.710^{9} \mathrm{~m}^{3}\right)$ and $\sim 22 \%$ of the runoff of the total catchment $\left(90010^{9} \mathrm{~m}^{3}\right.$ ) (Lin and $\mathrm{Wu}, 1999)$. Soil erosion in the upper Yangtze is estimated to reduce water storage at the rate of $0.2210^{9} \mathrm{~m}^{3}$ per year, the equivalent of $0.02 \%$ of annual runoff (Shi et al., 1999), which for comparison, is only $1 \%$ of the design flood storage of the Three Gorges Dam.

In fact, it is difficult to precisely quantify the impact of soil erosion on runoff in the Yangtze due to the uncertainty about the rate of water storage and release through the soil layers at the annual time scale. The effect of soil erosion appears to be more relevant to flood events and shows strong seasonal behavior (Yin and Li, 2001; Yu et al., 2009). As the most badly eroded regions are located in the upper Yangtze, any impacts are likely to be difficult to detect as far downstream as Datong. Soil erosion, in association with other aspects of land use in the mid-lower Yangtze, is believed to substantially worsen the flood hazard. The long term effects of soil degradation on the annual runoff are yet to be examined precisely.

Finally, rapid urbanization along the Yangtze River increases the impervious area within the catchment, yielding, on average, 5.7 times as much runoff per unit area as non-urban land (CWSC, 2011). The basin wide effect of large scale urbanization on the annual runoff of the Yangtze River has not yet been estimated; only a few small 
scale studies have been conducted (Yuan et al., 2006; Xu YP et al., 2010). Xu YP et al. (2010) observe that rapid urbanization tends to raise the annual runoff depth in the Yangtze delta region, and thus increase the risk of flooding in cities. However, the catchment scale effects are not yet known, though the overall effect of urbanisation would be towards an increase in catchment runoff because of the increase in impervious surface area.

It is difficult to draw robust conclusions about the effects of land use changes on water supply to Shanghai, other than to note that despite significant changes in vegetation cover, soil erosion, and rapid urbanization, discharge from the catchment has not changed much at all since 1950 (see above). Given this, we tentatively conclude that future changes in land use seem unlikely to be significant drivers of change in water yields from the river.

\subsection{Dams}

In the Yangtze catchment there are 46,000 reservoirs with total storage capacity in 2007 of $230.010^{9} \mathrm{~m}^{3}$ (about $25 \%$ of the annual flow). Most of these dams were constructed after 1949 (Yang et al., 2005a), but construction increased significantly during the period 1970-2000. In 2002 there were 162 large dams (storage capacity > $0.1 \mathrm{~km}^{3}$ ) in the catchment that can store nearly $155.44 \mathrm{~km}^{3}$, or $95 \%$ of the total storage volume. More large dams are planned for the upper Yangtze. Chen and He (2009) report that 5 reservoirs, each as large as the Three Gorges Dam, will be operational in the next 5-10 years. It is planned to construct an additional 184 new large dams in the Yangtze catchment by 2050, with a total volume of $222.83 \mathrm{~km}^{3}$ (Li et al., 2000).

The Three Gorges Dam has generated more concern and discussion than all the other dams in the catchment combined. The seasonal distribution of discharge at Yichang Station changed after the Three Gorges Dam was completed. From January to May (the low flow season), discharge increased by about $2000 \mathrm{~m}^{3} \mathrm{~s}^{-1}$ or $20 \%$, but discharge decreased by $5000 \mathrm{~m}^{3} \mathrm{~s}^{-1}$ or $40 \%$ from October to December (Lu et al., 2009). Despite widespread speculation in the popular and scientific literature of the Three Gorges Dam's drastic impacts on flow, it has no net impact on the total annual flow, but only affects seasonality (Chen et al., 2010). 
Since 2003, frequent droughts in China, especially the spring drought of 2011, have caused public concern about the role of dams. There has been much public speculation that the Three Gorges Dam intensified the 2011 drought, which affected 35 million people in central and eastern China, crippled shipping in the middle and lower reaches of the Yangtze River, and exacerbated power shortages at the start of the summer (Ivanova, N., 2011). However, following intense speculation in the media, the China Three Gorges Corporation released data to the press that clearly demonstrated that the operating practices at the dam, whereby during the drought period in 2011 more water was released from the dam than flowed in from upstream, actually meant flow downstream of the dam was higher than it would have been naturally (China Daily 24 May, 2011). The Corporation's claim is supported by Lu et al. (2011). The construction of dams for the purposes of hydropower is therefore not a major risk to water security in Shanghai; indeed, if managed well, they may help to ensure water security in periods of climate-induced shortages.

\subsection{Water-transfer projects}

Three major diversions, western, central and eastern, are now either planned or under construction to deliver water out of the Yangtze to basins in drier areas of northern China. The western diversion scheme would transfer water from the upper Yangtze and the Lancang into the upper reaches of the Yellow River but is at present only in the planning stage and no construction date has been set. Liu and Zheng (2002) give estimates of the amount of water that could be transferred by this route in the range $22.1-50010^{9} \mathrm{~m}^{3}$ per year though more recent estimates are much lower at $410^{9} \mathrm{~m}^{3}$ per year (water-technology.net, 2011).

The central route involves transfer of water from the Danjiangkou reservoir on the Han River, a northern tributary of the middle Yangtze (Figure 2), into northern China. This diversion system is currently under construction and when completed will be capable of transferring $14.510^{9} \mathrm{~m}^{3}$ per year (Baike.baidu.com, 2012). The eastern route is also still being constructed and has a design capacity of $18.910^{9} \mathrm{~m}^{3}$. When complete, the total south-north diversion capacity will be $37.410^{9} \mathrm{~m}^{3}$ (Wang et al., 2006).

The net outcome of water diversions, extractions and return flows in the Yangtze upstream of Datong are monitored by the Datong stream gauging station and, as 
pointed out above, there has been no significant change in annual flow at this station since it was established in 1951 . The $600 \mathrm{~km}$ of the channel downstream of Datong is in a heavily populated and economically developed area and includes the location of the eastern south-north water diversion intake as well as the water intake sites for Shanghai. There has been an increase in the transfer of water out of the lower Yangtze since the 1950s (Zhang et al., 2012). There were 64 water diversion projects of different kinds prior to 2000, with a total water capacity of $145.810^{9} \mathrm{~m}^{3}$ per year (Zhang and Chen 2003).

Wang et al. (2008) estimate that the critical discharge at Datong to minimize salt water intrusion into the estuary is $13,000 \mathrm{~m}^{3} \mathrm{~s}^{-1}$. Based on 40 years of flow records at Datong, Yang (2001) estimated that planned diversions could reduce runoff to the sea to less than $13,000 \mathrm{~m}^{3} \mathrm{~s}^{-1}$ in $71 \%$ of months. This appears to us to be unlikely since average monthly discharge at Datong is greater than $20,000 \mathrm{~m}^{3} \mathrm{~s}^{-1}$ for eight months of the year. Our own analysis of the daily flow data shows that $13,000 \mathrm{~m}^{3} \mathrm{~s}^{-1}$ is exceeded in more than $75 \%$ of days.

By 2010, the total diversion capacity from the lower Yangtze had grown to $649.610^{9}$ $\mathrm{m}^{3}$ per year $\left(54.110^{9} \mathrm{~m}^{3}\right.$ per month). If operated at full capacity these diversions exceed the average monthly runoff in November, January and February (less than $23.610^{9} \mathrm{~m}^{3}$; Figure 3). However, actual water diversion volumes fall far below this maximum capacity in the dry season (winter). Due to the low water level in the main stream in the dry season, most sluices and pumps can not take in water as the river level is too low; other limitations also reduce the actual volume of water extraction, such as the running time of the projects, the duration of the flood and ebb tides near sluices and pump stations, climate, and industrial, agricultural and domestic water demand (Zhang and Chen, 2003; Zhang et al., 2012).

The most significant threats to dry-season runoff are from those pumping intakes and sluices with pumps that continue to operate in the dry season. They have a combined capacity of $5600 \mathrm{~m}^{3} \mathrm{~s}^{-1}$, and actual water intake can reach $80-90 \%$ of capacity at dry times (i.e. when runoff in Datong is less than $11000 \mathrm{~m}^{3} \mathrm{~s}^{-1}$ ) (Zhang and Chen, 2003); so, the ratio of water intake volume to stream discharge can reach $50 \%$ in a dry season. This means that runoff into the estuary will be less than $6000 \mathrm{~m}^{3} \mathrm{~s}^{-1}$ at dry times, and this level of discharge is not sufficient to counterbalance the tidal force; as a result there is more saltwater intrusion into the estuary. 
Operation of the south-north diversions will exacerbate this problem, though just how serious this is will depend on the operating rules for the transfer scheme. To the extent that the transferred water will be used for irrigation it should be noted that the low flow periods in the Yangtze do not occur at the same time as the main irrigation demand in northern China.

Water diversion projects would therefore appear to be the major threats to water supply to Shanghai. It is this multitude of extractions, more than anything else, that does and may increasingly reduce discharge from the river at Shanghai to such an extent that salinity reduces the ability of Shanghai's water managers to extract fresh water from the Yangtze River. This vulnerability is largely beyond the control of the municipality as it is associated with development decisions of upstream users and, in the future, the water demands of users far away in the north of China.

\section{Water Quality}

The decision to increase the dependence of Shanghai on water from the Yangtze was made by the municipality in response to the pollution of Taihu and the Huangpu River, as well as local water pollution. Before 1987, freshwater to Shanghai came mainly from Taihu via the Huangpu because it was convenient and cheap. However, the increasing levels of water pollution and eutrophication in Taihu made it difficult to sustain the supply of clean water to Shanghai (Hu et al. 2010). Also, as noted earlier, water bodies on the delta and within the Shanghai Municipal Area are generally considered too polluted to be used as raw water in treatment plants. These factors caused the Shanghai government to reduce its reliance on the Taihu system in favour of the Yangtze estuary, so that by 2012, $70 \%$ of the water supply to Shanghai's water treatment plants will be sourced from Chenhang and Qingcaosha reservoirs, both of which draw their water from the Yangtze.

The Yangtze estuary is also affected by a range of pollutants, and in most cases the effect of these pollutants is that they increase the cost of water treatment. The biggest pollution problem is salt. The estuary is prone to periods of high salinity, on occasions too high (> 250ppm) to be used for the domestic water supply system. The increasing frequency of high salinity periods is the key issue for water supply from the estuary, especially in the dry season. Hydrological data from 1978 to 2003 show that when the 
minimum average monthly discharges were $7600 \mathrm{~m}^{3} \mathrm{~s}^{-1}$ (January, 1987), $9100 \mathrm{~m}^{3} \mathrm{~s}^{-1}$ (February, 1999), and $10300 \mathrm{~m}^{3} \mathrm{~s}^{-1}$ (in January, 2000), the numbers of consecutive days when water was unsuitable for use at the Chenhang Reservoir on the South Branch of the Yangtze Estuary were 13, 25 and 9 respectively (Gu and Yue, 2004). Salt intrusion is mainly controlled by upstream discharge and sea level. The frequency of salt intrusion has increased because of the growing number of diversion projects since the 1950s (Chen and Chen, 2000). On the other hand, the mean long-term sea level in the Yangtze River estuary is rising, with an average rate of long-term sea level rise of $2.7 \mathrm{~mm} / \mathrm{y}$ (Zheng and $\mathrm{Yu}, 1996)$. While there is a strong negative correlation between discharge at Datong and salinity in the estuary (Chen X et al., 2001), and a positive correlation between estuarine salinity and sea level, more detailed work is needed to forecast saltwater intrusion events accurately. Nevertheless, the major threat to water security in Shanghai is the likely increase in frequency and duration of salt-water intrusion events that affect its major intake sites. This risk arises from a combination of changes, most importantly those associated with potentially reduced flows due to water diversions, and increasing salinity due to sea-level rise.

\section{Conclusions}

While Biswas (2001) argues that the concern with water supply to megacities may be misplaced, as they are sufficiently powerful in political, economic and institutional terms to be able to effectively deal with these problems, this has not yet been reflected in significant improvements (Bakker 2010). The continuing rapid urban expansion of Shanghai has led to declining water (and air) quality, such that the abundant water locally available in the city cannot be used for water supply (Zhao et al., 2006) and water must be sourced from elsewhere. The current policy is to increase reliance on the Yangtze estuary.

The threats to Shanghai's water supply are therefore driven by a variety of hydroclimatic and social processes. Pollution in the immediate source area within and around Shanghai has led to increasing reliance on the Yangtze and this system is subject to changes that can have an impact on total annual flow and the seasonality of flow. In Table 1 we summarise these threats and list for each the main points of 
evidence, the nature of the impact and the level of confidence we have in this assessment. We have ranked the confidence level as high, medium and low depending on how the information is generated, whether from data collection of high accuracy and reliability (e.g. precipitation and discharge measurements) or poorly observed data lacking precise measurements (e.g. impacts of forest cover on discharge).

\section{Insert Table 1 about here}

Shanghai's access to potable water will be adversely affected by reductions in freshwater flow into the estuary where it sources its water. Given the strong seasonality of the flow regime and the very large flows in the summer semester (Figure 3), it is clearly the winter semester where the risk is serious. On this basis, those threats that affect summer flows are unlikely to be of concern. It should also be noted that many of the changes in the Yangtze catchment have the effect of increasing the discharge of the river and so do not pose a threat to the Shanghai water supply system while others may have a significant adverse impact close to where they occur but are difficult to detect at the whole-of-basin scale.

Degradation of the glaciers in the upper basin, that is already evident and likely to accelerate in the future, is significant at the local level but not of sufficient magnitude to have a measurable effect at the whole-of-basin scale. Changes in temperature and precipitation in the middle and lower basin have already affected the seasonal distribution of runoff with increasing runoff in summer and winter and a decrease in the spring and autumn. While this trend is predicted to continue under climate change scenarios, the nature and timing (seasonality) of the changes means they are unlikely to have a detrimental effect on water supply to Shanghai.

Dramatic increases in the area of forest cover will reduce the water yield of those areas though this is not yet detectable at the whole-of-basin scale. In any case, the season when fresh water supply in the estuary is limiting is winter when, because of the low evapotranspiration rates, the effect of increased forest cover on runoff is minimal. The loss of soil by erosion leads to increased runoff though there is, as yet, no detailed examination of this in the Yangtze basin. Runoff should also increase in response to increasing levels of urbanisation in the Yangtze basin but in this case also, no detailed analysis has yet been made. 
Since the middle and lower Yangtze basin lies in a humid climate zone with annual precipitation generally in excess of $1200 \mathrm{~mm}$ and concentrated in the growing season, dam building has been focussed on hydropower generation and flood control. The Three Gorges Dam will not change the total annual flow of the Yangtze but will change the seasonal distribution in ways that should be beneficial to Shanghai, that is, by reducing the flow in high flow periods and increasing it in months of low flow.

As shown in Table 1, we have high confidence in our assessments of the threats posed by the south to north water transfers and the salt water intrusions in the estuary. These two threats need to be viewed together and have the potential to seriously impact the supply of freshwater to Shanghai. While the total annual volumes to be diverted can be readily accommodated from the total annual flow of the Yangtze, the effect of these transfers on further reducing flows in the low flow period in winter and early spring (Figure 3) will exacerbate the problem of salt water intrusion into the estuary and thus limit the available freshwater supply to Shanghai at those times.

Thus the most serious threat to fresh water supply to Shanghai, at least over the next few decades, is salt-water intrusion into the estuary where the bulk of Shanghai's water is now sourced. This situation has been created by the decision of the Shanghai Municipal Government to locate its water intake stations in that part of the lower estuary where these incursions occur. This siting decision has the advantage of reducing pumping costs as compared with sites further upstream. It also means that the water is being sourced from within the boundaries of the province, thus eliminating any issues of inter-provincial politics. However, it renders Shanghai vulnerable to those situations where fresh water inflows are further reduced in the low flow months of the late winter in the context of a rising sea level.

This analysis points to the role of multiple stressors to water security in Shanghai. It also points to the relative importance of management decisions (relating to water diversions and the location of reservoirs) among these stressors. That these most significant of stressors are within the control of state-level, basin-level, and municipal water managers means that - at least in theory - Shanghai's water security is in the hands of the people more than it is dependent on changes in climate.

\section{Acknowledgements}


This research was supported by Australian Research Council grant number DP110103381. The authors thank Chandra Jayasuriya for drawing the figures.

\section{References}

Andreassian V (2004) Waters and forests: from historical controversy to scientific debate. J Hydrol 291:1-27

Baike.baidu.com (2012) South-to-north water transfer project, China. http://baike.baidu.com/view/26518.htm (In Chinese), Accessed 4 ${ }^{\text {th }}$ July, 2012.

Bakker K (2010) Privatizing water: governance failure and the world's urban water crisis. Ithaca NY, Cornell University Press

Biswas AK (2001) Missing and neglected links in water management. Water Science and Technology 43:45-50

Bueh C, Cubasch U, Hagemann S (2003) Impacts of global warming on changes in the East Asian monsoon and the related river discharge in a global time-slice experiment. Climate Research 24:47-57

Centre for Water Sensitive Cities (2011) Blueprint for stormwater management in a water sensitive city. Monash University, Clayton, Australia, Centre for Water Sensitive Cities

Changjiang Water Conservancy Commission (1950-2000) Yearbook of water and sediment. Wuhan, Changjiang Water Conservancy Commission, Unpublished Report Changjiang Water Conservancy Committee (2007) Soil and water conservation in the Yangtze River basin. Wuhan, Changjiang Water Conservancy Committee

Chen J, He Q (eds) (2009) Changiiang River, impact of extreme dry year of 2006 on the security of freshwater of Shanghai. Beijing, Ocean Publisher (in Chinese)

Chen X, Chen J (2000) Proposal to study and control of the decreasing tendency in discharge of the Changjiang River entering the sea in the dry season. Science and Technology Review 2:39-40 (in Chinese)

Chen X, Zong Y, Zhang E, Xu J, Li S (2001) Human impacts on the Changjiang (Yangtze) River basin, China, with special reference to the impacts on the dry season water discharges into the sea. Geomorphology 41:111-123 
Chen Z, Li JF, Shen HT, Wang ZH (2001) Yangtze River of China: historical analysis of discharge variability and sediment flux. Geomorphology 41:77-91

Chen Z, Wang Z, Finlayson BL, Chen J, Yin D (2010) Implications of flow control by the Three Gorges Dam on sediment and channel dynamics of the middle Yangtze (Changjiang) River, China. Geology 38:1043-1046

Chen Z, Xu S, Xu Q, Hu X, Yu L (2002) Surface water pollution in the Yangtze River delta: patterns and countermeasures. Pedosphere 12:111-120

China View (2009) Glacier thawing speeds up in Yangtze River sources. http://news.xinhuanet.com/english/2009-07/28/content_11788610.htm Accessed 10 Oct 2011

Deng H, Yu DW, Pu J (2011) At the water's edge. Caixin online. http://english.caixin.com/2011-06-16/100270117.html Accessed 30 June 2012. Falkenmark M (1986) Fresh water - time for a modified approach. Ambio 15:192200

Feng H, Dong QG, Wang WJ, Lu HM (2010) Effects of soil and water conservation on the flood disaster in the Yangtze Catchment. Soil and Water Conservation of China 10:2-4 (in Chinese)

Golley J (2010) Prospects for diminishing regional disparities. In: Garnaut R, Golley J, Song L (eds) China: the next twenty years of reform and development, ANU ePress, Canberra, pp 127-150

Gu YL, Yue Q (2004) Analysis and prediction of saltwater intrusion in Chenhang water source region in Yangtze River Estuary. Public Utilities 18:19-20 (in Chinese) Hallmark Environmental Technologies (undated, possibly 1999?), Shanghai water, http://hallmarkenvirontech.com/research. Accessed 27 May 2011

Han ML (2010) Analysis of the current water usage in the power plant and its future measure. Industrial Water Treatment 30:4-7 (in Chinese)

Hu LM, Hu WP, Zhai SH, Wu HY (2010) Effects on water quality following water transfer in Lake Taihu, China. Ecological Engineering 36:471-481

Hu S (2003) Thirsty for fresh water. Shanghai Star 17 July 2003 http://app1.chinadaily.com.cn/star/2003/0717/fo5-1.html Accessed 30 June 2012 
Immerzeel W, van Beek L, Bierken M (2010) Climate change will affect the Asian water towers. Science 328:1382-1385

Ivanova N (2011) Rains bring relief for six-month China drought, but chronic water problems loom. Circle of Blue

http://www.circleofblue.org/waternews/2011/world/rains-bring-relief-for-six-monthchina-drought/ Accessed 24 June 2012

Jiang T, Kundzewicz ZW, Su B (2008) Changes in monthly precipitation and flood hazard in the Yangtze River Basin, China. International Journal of Climatology 28:1471-1481

Jiang T, Su B, Wang Y, Zhang Q, Qin N (2005) Trends of temperature, precipitation and runoff in the Yangtze River basin from 1960 to 2000. Advances in Climate Change Research 1:65-69 (Chinese with English abstract)

Le F, Wang DG, Chen B (2011) Water quality modeling for a tidal river network: A case study of the Suzhou River. Frontiers of Earth Science 5:428-431

Li CA, Yin HF, Yu LZ (2000) Silt transform characteristics and latent effect on fluvial system environment in Yangtze River. Resources and Environment in the Yangtze Basin 9:504-509 (Chinese with English abstract)

Li F, Cheng J, Guo G (2008) Pollutant category and its source in Yangtze estuary. Jiangsu Environmental Science and Technology 1:10-15

Li WH (1999) Flood of Yangtze River and ecological restoration. Journal of Natural Resources 14:1-8 (Chinese with English abstract)

Li ZF, Yang GS, Li HP (2007) Estimation of nutrient export coefficient from different land use types in West Tiaoxi watershed. Journal of Soil and Water Conservation 1:15 (in Chinese)

Lin CK, Wu XG (1999) A study on characteristics of runoff amount and its important significance at the Yangtze. Ziran Zazhi 21:200-205 (Chinese with English abstract) Liu C, Zheng H (2002) South-to-north water transfer schemes for China. Water Resources Development 18: 453-471

Liu S, Zhang Y, Zhang Y, Ding Y (2009) Estimation of glacier runoff and future trends in the Yangtze River source region, China. Journal of Glaciology 55:353-362 
Lu C, Liang C (2011) Climate change threatens our water. China Daily 23 April 2011

Lu G, Liu Y, Zou X, Zou Z, Cai T (2009) Impact of the Danjiangkou Reservoir on the flow regime in the middle and lower reaches of Hanjiang River. Resources and Environment in the Yangtze Basin 18:956-961

Lu X, Yang X, Li S (2011) Dam not sole cause of Chinese drought. Nature 475 (7355): 174

McDonald RI, Green P, Balk D, Fekete BM, Revenga C, Todd M, Montgomery M (2011) Urban growth, climate change, and freshwater availability, Proceedings of the National Academy of Sciences 108:6312-6317

McMahon TA, Finlayson BL, Haines AT, Srikanthan R (1992) Global Hydrology. Cremlingen, Catena Paperback

N'Dow 1996 Water crisis to strike most developing world cities by 2010 Istanbul: Habitat II, available at http://www.un.org/Conferences/habitat/unchs/press/ Accessed 13 September 2011

National Research Council (1996) Water and sanitation services for megacities in the developing world. Meeting the challenges of megacities in the developing world: A collection of working papers. Washington, DC. The National Academies Press

Qin N, Jiang T, Xu C (2005) Trends and abruption analysis on the discharge in the Yangtze Basin. Resources and Environment in the Yangtze Basin 14:589-594

(Chinese with English abstract)

Shanghai Municipal Government (2009) Encyclopedia of Shanghai.

http://zhuanti.shanghai.gov.cn/encyclopedia/en/ accessed 29 June 2012

Shanghai Municipal Government (2010) Answers to people's questions on

Qingcaosha water source. (解答青草沙源头市民们关注问题)

http://www.shanghai.gov.cn/shanghai/node2314/node2315/node4411/u21ai462009.ht $\mathrm{ml}$

Shanghai Water Authority, (2006) Shanghai Water Resource Bulletin, http://www.shanghaiwater.gov.cn/web/sw/2006_1_1.jsp, Accessed 4th July 2012.

Shanghai Water Authority, (2007) Shanghai Water Resource Bulletin, http://www.shanghaiwater.gov.cn/web/sw/2007_1_1.jsp, Accessed 4th July 2012. 
Shanghai Water Authority, (2008) Shanghai Water Resource Bulletin, http://www.shanghaiwater.gov.cn/web/sw/2008_1_1.jsp, Accessed 4th July 2012.

Shanghai Water Authority, (2009) Shanghai Water Resource Bulletin, http://www.shanghaiwater.gov.cn/web/sw/2009_1_1.jsp, Accessed 4th July 2012.

Shanghai Water Authority, (2010) Shanghai Water Resource Bulletin, http://www.shanghaiwater.gov.cn/web/sw/2010_1_1.jsp, Accessed 4th July 2012.

Shi XZ, Liang Y, Yu DS (1999) Soil reservoir and control of flood calamity in Yangtze River watershed. Journal of Soil Erosion and Soil and Water Conservation 5: 6-10 (Chinese with English abstract)

Shi Y, Liu C, Wang Z, Liu S, Ye B (2005) A concise China glacier inventory. Shanghai, Shanghai Science Popularization Press (in Chinese)

Shi Y, Zhu J, Xie Z, Ji Z, Jiang Z, Yang G (2000) Prediction and prevention of the impacts of sea level rise on the Yangtze River Delta and its adjacent areas. Science in China (Series D) 43:412-422

State Statistical Bureau, PRC (2011) China population yearbook 2010. Statistics Press, Beijing (In Chinese)

Tang J, Xu H, Wang Z (2009) Changes in summer monsoon precipitation over Hunan Province during 1952-2007: response to the west Pacific sea surface temperature and global warming. Frontiers of Earth Science in China 3:411-418

Varis O, Kummu M, Salmivaara A (2011) Ten major rivers in monsoon Asia-Pacific: an assessment of vulnerability. Applied Geography 32:441-454

Wang C, Wang Y Y, Wang P F (2006) Water quality modeling and pollution control for the Eastern route of South to North water transfer project in China. Journal of Hydrodynamics 18:253-261

Wang GQ (2010) Growth threatens China's water supply. Xinhua News Agency, 9 December. available at http://china-wire.org/?p=7893. Accessed 23 May 2011 Wang Y, Huang H, Li X (2008) Critical discharge at Datong for controlling operation of South-to-North Water Transfer Project in dry seasons. Water Science and Engineering 1:47-58 
Wang, HR (2011) Thirsty cities, dirty water Beijing Review 54(15), 14 April 2011. http://www.bjreview.com/nation/txt/2011-04/08/content_349958.htm. Accessed 2 July 2012

Ward R M, Liang W (1995) Shanghai water supply and wastewater disposal.

Geographical Review 85:141-157

water-technology.net (2011) South-to-north water diversion project, China. http://www.water-technology.net/projects/south_north. Accessed 24 June 2012

Wei XH, Sun G, Liu SR, Jiang H, Zhou GY, Dai LM (2008) The forest-streamflow relationship in China: A 40-year retrospect. Journal of the American Water Resources Association 44:1076-1085

Wei ZX, Zai GY, Yan XX (eds) (2010) Shanghai Urban Geology. Beijing, Geology Press

World Resources Institute (2003) Watersheds of the world CD. Washington DC, World Resources Institute

World Wide Fund for Nature (2011) Living Yangtze. http://wwfcn.panda.org/en/what_we_do/living_yangtze/ Accessed 13 December 2011 Xie C, Ding Y, Liu S (2004) Changes of weather and hydrological environment for the last 50 years in the source regions of Yangtze and Yellow Rivers. Ecology and Environment 13:520-523 (Chinese with English abstract)

Xu K, Milliman JD, Xu H (2010) Temporal trend of precipitation and runoff in major Chinese Rivers since 1951. Global and Planetary Change 73:219-232

Xu YP, Xu JT, Ding JJ, Chen Y, Yin YX, Zhang XQ (2010) Impacts of urbanization on hydrology in the Yangtze River Delta, China. Water Science and Technology 62:1221-1229

Yang G S (2001) Impacts of the construction of key water conservancy projects in the Yangtze River and sea level rise on water quality of Shanghai water intake. Scientia Geographica Sinica 21:123-129 (in Chinese)

Yang J, Ding Y, Liu S, Lu A, Chen R (2003) Glacier change and its effect on surface runoff in the source regions of the Yangtze and Yellow Rivers. Journal of Natural Resources 18:595-602 (Chinese with English abstract) 
Yang S L, Gao A, Hotz HM, Zhu J, Dai S B, Li M (2005) Trends in annual discharge from the Yangtze River to the sea (1865-2004). Hydrological Sciences Journal $50: 825-836$

Yang SL, Zhang J, Zhu J, Smith JP, Dai SB, Gao A, Li P (2005a) Impact of dams on Yangtze River sediment supply to the sea and delta intertidal wetland response.

Journal of Geophysical Research doi:10.1029/2004JF000271

Yang SL, Milliman JD, Li, P, Xu K (2011) 50000 Dams Later: Erosion of the Yangtze River and its Delta. Global and Planetary Change 75:14-20

Yin HF, Li CG (2001) Human impact on floods and flood disasters on the Yangtze River. Geomorphology 41:105-109

Yu FL, Chen ZY, Ren XY, Yang GF (2009) Analysis of historical floods on the Yangtze River, China: Characteristics and explanations. Geomorphology 113:210-216 Yuan W, James P, Yang K (2006) Impact of urbanization on structure and function of river system - case study of Shanghai China. Chinese Geographical Science 16:102108

Zeng X, Su B, Jiang T, Chen Z (2007) Projection of Future Climate Change in the Yangtze River Basin for 2001-2050. Advances in Climate Change Research 3:293298 (Chinese with English abstract)

Zhang C (1997) Case study II - Shanghai Huangpu River, China. In: Helmer R, Hespanhol I (Eds), Water pollution control - a guide to the use of water quality management principles. London, United Nations Environment Programme, Water Supply \& Sanitation Collaborative Council and the World Health Organization, E. \& F. Spon pp290-314

Zhang E F, Chen X Q (2003) Changes of water discharge between Datong and the Changjiang Estuary during the dry season. Acta Geographica Sinica 58:231-238 (in Chinese)

Zhang EF, Savenije H HG, Chen SL, Chen JY (2012) Water abstraction along the lower Yangtze River, China, and its impact on water discharge into the estuary. Physics and Chemistry of the Earth doi:10.1016/j.pce.2011.05.002

Zhang JD (1999) Whether the treated domestic sewage can be used in the power plant? Industrial Water Treatment 3:5-7 
Zhang Q, Xu C, Zhang Z, Chen YD, Liu C, Lin H (2008) Spatial and temporal variability of precipitation maxima during 1960-2005 in the Yangtze River basin and possible association with large-scale circulation. Journal of Hydrology 353:215-227

Zhao S, Da L, Tang Z, Fang H, Song K, Fang J (2006) Ecological consequences of rapid urban expansion: Shanghai, China. Frontiers in Ecology and the Environment $4: 341-346$

Zheng DW, Yu NH (1996) Research on the long-range forecast for the trend of sea level rising in the area of Shanghai, Annals of Shanghai Observatory Academia Sinica 17:36-45 (in Chinese)

Zhu M (1994) Preliminary study on water quality protection in Lake Taihu. In: Sund H, Yu X, Stabel H, Yuan K, Geller W, She F (eds) Environmental protection and lake ecosystem. Beijing, China Science and Technology Press pp 269-279 


\section{Figure Captions}

Figure 1. Shanghai water use by sector, averaged over the period 2006-2010, showing the proportion of water supplied to each sector by the public supply system operated by the Shanghai Water Authority and the proportion sourced directly by the user. Data source: Shanghai Water Authority, 2006-2010.

Figure 2. Location map with detail of the lower Yangtze and Taihu (A) and the glacier area of Gelandandong in the upper catchment (B).

Figure 3. Yangtze River at Datong. Monthly average flows $1951-1984$ (+) and maximum and minimum flow( -) recorded in each month. Month 1 is January. Data source: Changjiang Water Conservancy Commission 1950-2000.

Table 1. Summary of threats to Shanghai water supply, the evidence for those threats, the nature of the impact and assessed level of confidence in the evidence.

\begin{tabular}{|l|l|l|l|}
\hline Threat & Evidence & Nature of Impact & Confidence \\
\hline $\begin{array}{l}\text { Glacier } \\
\text { degradation }\end{array}$ & $\begin{array}{l}\text { - Measurements of glacier } \\
\text { volumes } \\
\text { - Contribution of glacier } \\
\text { derived runoff to Yangtze } \\
\text { discharge }\end{array}$ & $\begin{array}{l}\text { Very small. Glacier } \\
\text { meltwater is only } \\
\sim 0.014 \% \text { of Yangtze } \\
\text { discharge }\end{array}$ & High \\
\hline $\begin{array}{l}\text { Temperature } \\
\text { and } \\
\text { precipitation } \\
\text { changes }\end{array}$ & $\begin{array}{l}\text { - Past records of } \\
\text { precipitation and } \\
\text { temperature }\end{array}$ & $\begin{array}{l}\text { Discharge has } \\
\text { increased in winter and } \\
\text { summer and decreased } \\
\text { in spring and autumn }\end{array}$ & High \\
& $\begin{array}{l}\text { - Modelling based on } \\
\text { climate predictions of the } \\
\text { IPCC }\end{array}$ & $\begin{array}{l}\text { Increase in discharge } \\
\text { early and mid summer, } \\
\text { decrease in in late }\end{array}$ & Medium \\
\hline
\end{tabular}




\begin{tabular}{|c|c|c|c|}
\hline & & $\begin{array}{l}\text { summer and autumn up } \\
\text { to } 12-16 \%\end{array}$ & \\
\hline $\begin{array}{l}\text { Land Use } \\
\text { Changes: } \\
\text { - Vegetation } \\
\text { changes }\end{array}$ & $\begin{array}{l}\text { Observed changes in } \\
\text { forest cover in the upper } \\
\text { Yangtze basin }\end{array}$ & $\begin{array}{l}\text { Small change } \\
\text { (increase?) in discharge } \\
\text { difficult to detect at } \\
\text { whole basin scale }\end{array}$ & Low \\
\hline - Soil erosion & $\begin{array}{l}\text { Published observations of } \\
\text { soil erosion }\end{array}$ & $\begin{array}{l}\text { Suggested increase in } \\
\text { discharge difficult to } \\
\text { detect at whole basin } \\
\text { scale }\end{array}$ & Low \\
\hline - Urbanisation & $\begin{array}{l}\text { Increased level of } \\
\text { urbanisation in the } \\
\text { catchment }\end{array}$ & $\begin{array}{l}\text { Would increase runoff } \\
\text { in theory but actual } \\
\text { amounts not known }\end{array}$ & Low \\
\hline Dams & $\begin{array}{l}\text { Large dams in the basin } \\
\text { mainly for hydroelectricity } \\
\text { and more planned and } \\
\text { under construction }\end{array}$ & $\begin{array}{l}\text { Change flow } \\
\text { seasonality by reducing } \\
\text { summer semester flow } \\
\text { and increasing winter } \\
\text { semester flows }\end{array}$ & High \\
\hline $\begin{array}{l}\text { Water transfers } \\
\text { to northern } \\
\text { China }\end{array}$ & $\begin{array}{l}\text { South to north transfers in } \\
\text { central and eastern basin } \\
\text { now being constructed }\end{array}$ & $\begin{array}{l}\text { Reduction in flow in } \\
\text { Yangtze estuary, } \\
\text { critical in low flow } \\
\text { period }\end{array}$ & High \\
\hline Water quality & $\begin{array}{l}\text { High salinity events in the } \\
\text { Yangtze estuary }\end{array}$ & $\begin{array}{l}\text { Raise salinity above the } \\
\text { potable level in months } \\
\text { of low flow }\end{array}$ & High \\
\hline
\end{tabular}




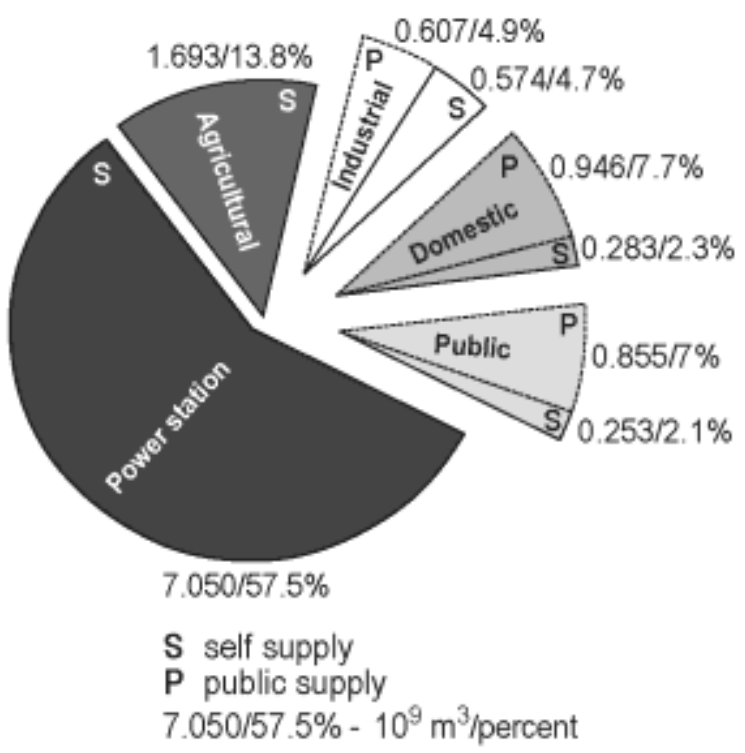



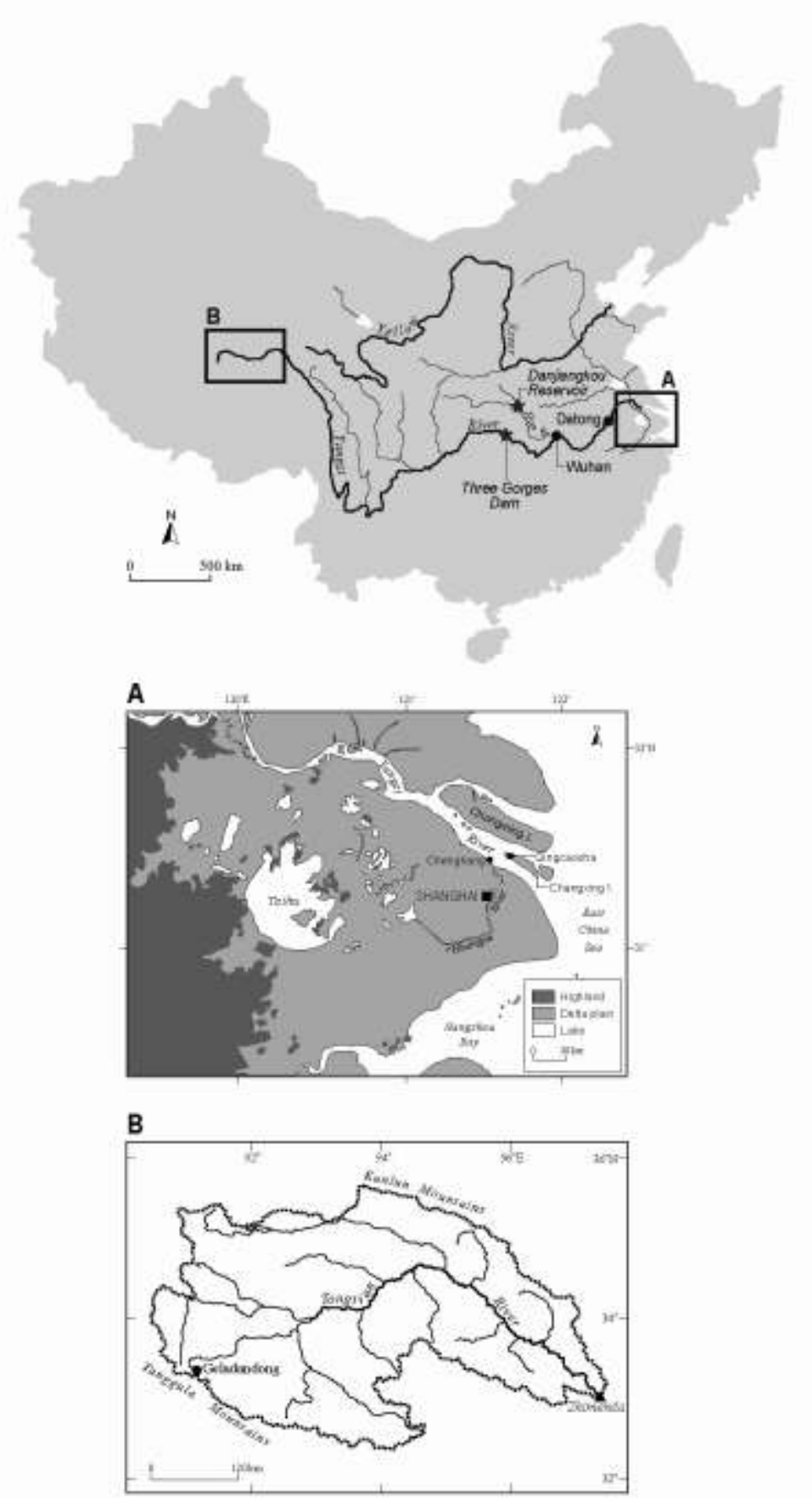


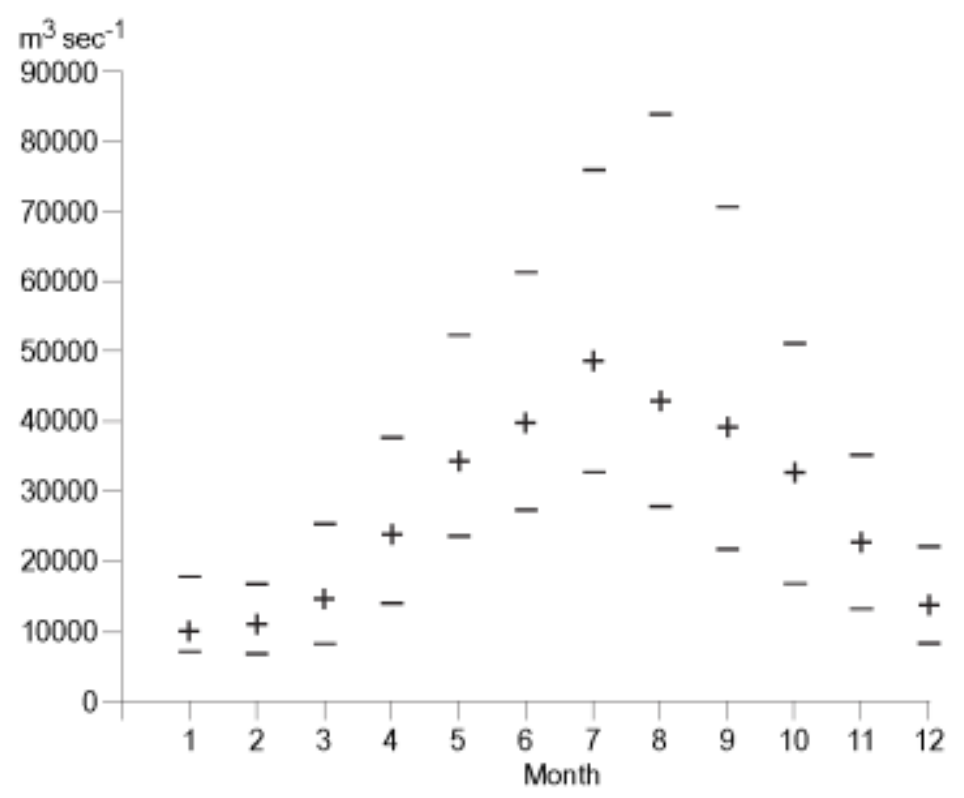




\section{University Library}

\section{- M M N E R VA A gateway to Melbourne's research publications}

Minerva Access is the Institutional Repository of The University of Melbourne

Author/s:

Finlayson, BL;Barnett, J;Wei, T;Webber, M;Li, M;Wang, MY;Chen, J;Xu, H;Chen, Z

Title:

The drivers of risk to water security in Shanghai

Date:

2013-04-01

Citation:

Finlayson, B. L., Barnett, J., Wei, T., Webber, M., Li, M., Wang, M. Y., Chen, J., Xu, H. \& Chen, Z. (2013). The drivers of risk to water security in Shanghai.

REGIONAL ENVIRONMENTAL CHANGE, 13 (2), pp.329-340. https://doi.org/10.1007/ s10113-012-0334-1.

Persistent Link:

http://hdl.handle.net/11343/282643 